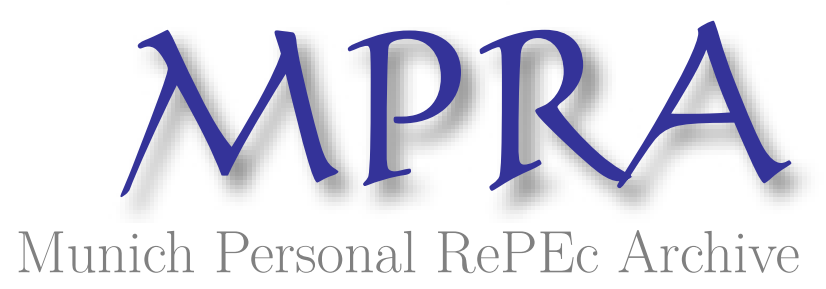

\title{
Employer-provided training and knowledge spillovers: evidence from Italian local labour markets
}

Croce, Giuseppe and Ghignoni, Emanuela

Sapienza, University of Rome

April 2009

Online at https://mpra.ub.uni-muenchen.de/14475/

MPRA Paper No. 14475, posted 04 Apr 2009 18:20 UTC 


\title{
Employer-provided training and knowledge spillovers. Evidence from Italian local labour markets *
}

\author{
Giuseppe Croce $^{\mathrm{a}}$, Emanuela Ghignoni ${ }^{\mathrm{b}}$
}

This version: April 2009

\begin{abstract}
Following suggestions from theoretical and empirical literature on agglomeration and on social returns to education which emphasise the contribution of local knowledge spillovers to productivity and wage growth, this paper aims at uncovering the relationship between local human capital and training. Furthermore, we check the effects of other variables measuring distinctive features of local labour markets, like the degree of specialization, average firms' size, intensity of job turnover, economic density, employment in R\&D activities and some other control variables.

Our key-results are consistent with the prediction that training should be more frequent in areas where the aggregate educational level is higher. Moreover, interaction between local and individual human capital is positive and significant for those with an upper secondary educational attainment. These results have proved to be robust since they are not altered when different definitions of local human capital are adopted or different sub-samples are considered (with the exception of female workers). We coped also with the problem of omitted variables and spatial sorting, that could bias econometric results, by means of a two-step strategy based on instrumental variables.
\end{abstract}

JEL codes: J24; O15; O18; R23

Keywords: training; knowledge spillovers; local labour markets

\footnotetext{
${ }^{*}$ We acknowledge ISFOL for providing us with data from the survey Plus (2005). Micro-data use authorization codes Isfol PLUS 2005/0022-0023. We are grateful to Emanuela Gaeta and Andrea Ricci for helpful comments on earlier version of this paper. Usual disclaimers apply.

${ }^{\text {a }}$ Sapienza - University of Rome, Department of Public Economics.

${ }^{\mathrm{b}}$ Sapienza - University of Rome, Department of Public Economics.
} 


\section{Introduction.}

The incidence of workers' training varies widely across countries according to differences in economic structures and national institutions. Nevertheless other relevant factors influencing training investments operate at a lower territorial scale and can be identified by comparing local labour markets. This paper aims at looking for local factors influencing training provided by the employers. In particular we are interested in verifying whether training sponsored by the firms is affected by local knowledge spillovers.

Previous results from researches on agglomeration economies and on social returns on higher education suggest that knowledge spillovers can be generated by human capital embodied in labour supply located in an area and have a positive influence on local productivity and wages (Moretti 2004, Rosenthal and Strange 2004, Henderson 2006). Thus it seems plausible to hypothesise that also the incentives to training can be altered by them in some way. Few other papers investigated the relationship between economic density and training and found out that the incidence of training is negatively affected by local density (Brunello and De Paola 2008, Muehlemann and Wolter 2006, Brunello and Gambarotto 2007). They explain this result by arguing that the negative effect of higher turnover and poaching associated to denser areas prevails on the positive effect which could derive from knowledge spillovers.

Unlike previous papers, our analysis focuses on area-specific measures of human capital, rather than on economic density, as a source of externalities and on its effects on the probability that a worker is offered a training opportunity by the firm. To carry out this analysis we exploit information collected through an extensive survey on workers and data from various sources on Italian local labour markets (LLMs) identified as travel-to-work areas and covering the whole national territory.

According to theory, learning does not take place as a solitary activity but it is based on interactions which often consist of 'face-to-face' relationships (Duranton and Puga 2004). Moreover, local interactions can allow not only radical innovations but also 'everyday incremental knowledge creation, diffusion and accumulation'. Following Duranton and Puga (2004) proximity makes easier the exchange and diffusion of knowledge. 
One basic idea of theoretical explanations for agglomeration economies is that knowledge accumulated by agents in a local environment can be helpful to other agents. Several papers test this intuition by estimating the impact of the level of local education on wages (Rauch 1993, Moretti 2004). Moretti (2004) provides evidence of a positive effect on wages for US, which is confirmed even after taking into account econometric difficulties due to omitted variables and imperfect substitution between educated and non educated labour (see also Ciccone and Peri 2006). Dalmazzo and De Blasio (2007) show similar results for Italy by estimating the relationship between local human capital and average wages at the local level. Based on data from the same survey, Di Addario and Patacchini (2008) finds that wages rise with population size. Moreover, they show that returns to academic skills are decreased by it while, on the contrary, returns to job qualification are increased. Both these papers consider, as well as we do, local labour markets corresponding to travel-to-work areas as identified on the basis of commuting data from Census.

At an individual level, previously acquired human capital raises the probability of further human capital investment. In particular, complementarity between education and workplace training represents a well recognised fact. According to it, workers with a high level of education face a higher probability to take training (Arulampalam et al. 2003). A similar complementarity can exist between local education and training. Indeed a major idea in this paper is that a larger endowment of human capital in an area, as measured by the aggregate level of education, gives rise to richer and more intense knowledge spillovers in the local labour market. Moreover we assume that a worker has to possess adequate skills in order to be able to absorb and valorise such a knowledge. Thus learning from skilled people requires that learners too possess some skills so that a sort of complementarity between local aggregate skills and individual skills emerges.

Then, while the standard effect of training is that it raises worker's productivity by improving his/her ability to perform his/her job, in local labour markets provided with a large presence of educated people training further increases worker's productivity by enabling him/her to 'catch' the knowledge spillovers in the area ${ }^{1}$. In a similar way, the firm innovation aptitudes can take advantage of its workers' ability to absorb

\footnotetext{
${ }^{1}$ A similar externality could arise inside the firm assuming that the presence of a high-talented worker raises the average ability of his/her colleagues. As a result, it is demonstrated that the employer could be more willing to sustain the cost of training (Booth and Zoega 2008).
} 
technological knowledge generated by other agents in the local economy. As a consequence, the return on training is increased and, under suitable conditions of imperfect competition in the labour market, the firm can be motivated to pay for it. In this framework the productivity gain associated to training can be conceived as an increasing function of the local educated share. Thus the probability of training is expected to be higher in areas where the aggregate educational level is higher.

On the other hand, an opposite effect could arise as a result of the fact that overall mobility can increase in parallel to the share of more educated people in the labour market, so that the firms would be discouraged from offering training (workers turnover in the private sector in Italy increases with the level of education, as showed by Trivellato et al. 2005). If this effect prevails, a negative relationship between aggregate education and the probability of training would result in our estimates.

In Brunello and Gambarotto (2007) training probability results to be unaffected by the local stock of human capital while Brunello and De Paola (2005) do not consider this effect. The results of Muehlemann and Wolter (2006) are not fully comparable with our results as they concentrate on apprenticeship training. We use two possible measures of local human capital stock, the share of population with high-school diplomas and college degree and the average years of education of the population in the area. Despite their limitations, both these measures are usually taken as proxies of the knowledge level in the area (Henderson 2007).

\section{Further factors influencing training in local labour markets}

Besides local education we examine the effect of individual and firm's characteristics and other factors shaping labour mobility in LLMs or representing possible sources of local external effects. Empirical research on factors affecting the probability that employer-sponsored training occurs mostly focuses on individual-level effects. As for these effects, a quite large consensus has been reached in literature (Bassanini et al. 2007). Thus, given detailed information provided by our dataset, we consider a set of individual variables including gender, age, level of education, final mark at school or university, labour contract, specific experience, firm's industry and size. On the contrary, much less evidence is available till now as for the effects of aggregate factors, so that this paper aims at offering some advancements to this regard. 
Human capital theory demonstrated that employer's propensity to train its employees, when skills are not perfectly specific, depend on structural features of labour market under the hypothesis of imperfect competition (Acemoglu and Pischke 1998, Leuven 2005). In particular, factors shaping labour mobility and wage compression are presumed to impinge on training offer. Briefly, the firms' incentive to train increases with wage compression, given by the gap between productivity and wage paid to the trained worker, and with frictions hindering labour mobility, as both these elements increase the expected return to training for the firm (Stevens 1996). Empirical evidence for Italy supports the assumption of a wedge between productivity and wages. Conti (2005) and Colombo and Stanca (2008) confirm that training leads to an increase of productivity larger than that of wages. Moreover, Colombo and Stanca (2008) finds that the effect of training on productivity is positive and significant when blue-collars are trained and is smaller in case of training of white-collars.

Our list of local variables encompasses the degree of specialization, the average firms' size, the intensity of job turnover, economic density, concentration of employment in R\&D activities and some other control variables. A higher specialization $^{2}$ implies that a larger share of economic activities results to be homogeneous and this makes easier skills transferability and labour mobility in the local labour market. Other things being equal, this in turn is expected to reduce training offered by the firms (Brunello and Gambarotto 2007). On the other hand specialization represents a possible source of externalities with possible positive effects on training, so that the sign of its effect it is an empirical matter.

In an area where the average size of firms is lower labour turnover and the risk of poaching are higher as every employer finds it more convenient to recruit skilled workers from other firms and, at the same time, is afraid of loosing his skilled workers. As a consequence, the overall offer of training by the employers tends to be lower than in otherwise identical areas.

Local economies vary considerably by the intensity of job turnover, which depends on the magnitude and the nature of idiosyncratic shocks and different paths of structural changes affecting each area. In principle, industrial shifts involving a larger share of employment are expected to require a more intense labour force adaptation, even by resorting to training and re-training activities. However, as structural changes raise

2 In our model "specialization" is measured by a dummy variable taking value 1 if the LLM was considered a specialised LLM by ISTAT (2007) on the basis of Census data on employment in 2001, and 0 if it was included in the residual group of LLMs without specialisation. 
employment instability, an opposite effect it is likely to prevail when training offered by the employers is considered, since a more intense turnover could discourage firms from sustaining the costs of training. We include in our model a measure of job turnover corresponding to the overall number of jobs created and destroyed in the main sectors in the LLMs from 2001 to 2005 relative to the stock of employment at the beginning of the period. This represents only a lower limit of the overall gross workers' turnover generated by destruction and creation of jobs and corresponding to the total amount of workers' associations and separations in a given period.

Also economic density, as measured by the ratio of the number of employees to the number of squared kilometres of the area, can have opposite effects. Following the discussion by Brunello and De Paola (2008), it tends to reduce training if it fosters mobility of skilled workers. On the other hand, it could affect positively training investments if knowledge spillovers are more intense in denser areas and skills are complementary to them. These authors find a negative relationship between density and training and a similar result is obtained by Muehlemann and Wolter (2006) and Brunello and Gambarotto (2007).

In the knowledge economy innovation activities are concentrated across areas according to area-specific factors and the availability of high specialised inputs. Although innovative activities tend to agglomerate in urban areas, a relevant part of them is located in more peripheral sites in Italy (Trigilia e Ramella 2008). In our model we measure the presence of innovation activities by the percentage of employment in R\&D in each LLM. The hypothesis to be tested is that a larger share of employment in R\&D generates knowledge spillovers in the local economy and gives more incentives to training if skills complement such spillovers.

Labour and training policies are important factors affecting the probability of training. Nevertheless, the LLM does not correspond by definition to the administrative territorial units (as Provinces and Regions) which would be more relevant in order to detect area-specific policy effects. For this reason no variables representing direct measures of training policies - e.g. per-employee public subsidy - are available for our analysis and we have to rely on proxy variables. In particular, we introduce macroregional dummies, as a way of capturing all policy dimensions (in particular resources devoted to workplace training and effectiveness of measures implemented) which are common to LLMs located in the same region. We add also the local unemployment rate whose effect is ambiguous a priori. In fact, it is plausible that the amount of public 
resources devoted to active labour market measures, included workplace training, is larger in regions and areas where labour market do not operate efficiently and this could rise the frequency of training. Moreover, other things being equal, unemployment weakens worker's bargaining strength (Acemoglu and Pischke 1999) and discourages voluntary quits making it more profitable training for the firm. On the contrary, one can argue that higher unemployment lessens firms' propensity to train by increasing the availability of unemployed skilled workers in the local labour market (Brunello and Medio 2001).

Then we include in the model some further controls whose purpose is to avoid that the effects of other relevant omitted variables distort the results obtained. The first one is LLM labour productivity to avoid that a possible spurious relationship between aggregate education and the probability of training arises since higher productivity could attract more highly educated people and, at the same time, tends to foster training activities in the same areas. Finally, to control for the size of the LLM, we insert the stock of population which in Di Addario and Patacchini (2008) results to have an influence on local wages.

\section{The econometric specification and the data description}

The data we utilise for the econometric estimations are drawn from the ISFOLPLUS dataset 2005. The ISFOL-PLUS survey contains information on the characteristics of over 40,000 individuals, selected according to their status of participation to the labour market. The employed group is composed by 16,397 individuals. Given our aim of estimating the probability of employer-provided training, we restrict our attention to private sector dependents only (7,912 individuals). Moreover, since the survey questionnaire investigates on a three years training participation, we further restrict our sample to those declaring an employment status persisting for three years or more (that is, since 2002). This should guarantee that the sample, other things being equal, is balanced in terms of training opportunities of the representative worker. Finally, due to the particular features of Italian young labour markets we selected individuals aged 20 or more, which leads to a further sample reduction $(6,980$ individuals).

The main question on training participation in the survey is as follows: "During the last three years have you participated to any seminar, convention, training or 
professional refresher course?" (question D175). In case of a positive answer the individual is asked to report additional information ("Was this course free or charged for?", D177) that allows to distinguish, within certain limits, whether training cost was borne by the firm or others (the worker or public institutions). In our sample 1,399 individuals (20\%) participated to employer-provided training (table 1).

We concentrate on employer-provided training and we assume that the probability that a worker receives this type of training depends not only on individual and firmspecific variables but also on local aggregated effects, with particular reference to local human capital.

More in detail, we use the following probit specification:

$$
\operatorname{Pr} o b\left\{T_{i j}=1\right\}=\Phi\left\{\beta X_{i j}+\gamma H C_{j}+\delta Y_{j}+\varepsilon_{i j}\right\}
$$

where $T$ is employer provided training, $X$ is a vector of individual and firm-specific observable characteristics, $H C$ is a measure of local aggregated human capital, $Y$ is a vector of confounding area-specific effects and the indices $i$ and $j$ refer to the individual and the local area. The first goal of the paper is to estimate $\gamma$, that is the impact of local human capital on training. To this aim we identify the local area with the local labour market (LLM) and we integrate the dataset ISFOL-PLUS with data from various sources on Italian LLMs (mostly from Atlante dei Comuni ISTAT).

For our purpose LLMs can be defined as areas corresponding to groups of neighbouring municipalities, belonging or not to the same Region, aggregated on the basis of data on daily commuting for working reasons in a way that most of the residents also work in the area (ISTAT 2007). This mostly eliminates from our analysis the problem of the incidental mismatch between area of residence and area of work.

\section{The estimation results}

We start by estimating a baseline specification, which includes only individual and firm-specific effects (table 2, column 1). Our estimates confirm some well-known outcomes in economic literature. Employees working full time, having a permanent contract, with higher education degree and a longer specific experience face a higher probability of receiving employer-provided training. We also found that male workers are more likely to be trained than their females counterparts. Moreover we observe that a better "quality" of individual learning at school or university (corresponding to 
having get a high final mark) positively affects the probability of training. As expected, training varies by sector and increases with firm size.

As for local factors, the local human capital indicators utilised in the estimations reported in table 2, columns (2), (3) and (4), that is the percentage of upper secondary graduates, the percentage of upper secondary and tertiary graduates and the average years of schooling in the local area, respectively, have a positive and significant impact. This is to say that if we consider two identical individual living in two otherwise identical areas, the one who is in the area with a higher share of educated population has a greater probability of receiving training from his/her employer. By contrast the percentage of individuals possessing a university degree does not have a significant effect $^{3}$.

Our result only partially agrees with the outcomes from previous papers examining the issue of externalities arising from local human capital. Brunello and Gambarotto (2007) shows a negative effect of economic density on training in UK but does not find any significant effect of average years of schooling, while Brunello and De Paola (2008), which confirms that density lessens training on Italian data, does not control for the local human capital. However, Dalmazzo and De Blasio (2007) finds important knowledge spillovers by estimating the effect of the average years of schooling on average wages in Italian LLMs.

Beside education, even our measure of job turnover is proved significant. The result indicate that a more intense job turnover lowers the probability of training. As we previously noted, the sign of the influence of job creation and destruction processes on training is not clear a-priori. On the one hand, it could require a need for training activities. On the other hand it raises employment instability and lowers expected returns to training. Then, we can conclude that the latter effect prevails and that turbulence in the local labour markets discourages firms from sustaining the costs of training. This evidence is also relevant for policy implications since it provides some scope for policy intervention when the economy undergoes rapid structural changes which would require larger workforce skills adaptations but depress firms' incentives to training.

Finally, unlike previous papers reporting a negative effect of local unemployment on average wages in the area (Dalmazzo and de Blasio, 2007, and Di Addario and Patacchini, 2008), we do not find any significant effect of unemployment on the

\footnotetext{
${ }^{3}$ In order to save space we do not present these results. The complete estimates are available upon
} request from the authors. 
probability of employer-provided training. Similarly, this is noto influenced by the other local variables considered in the model.

Having established that local human capital yelds to an increase in the training probability, we now ask if this effect benefits more workers with a secondary or tertiary degree by interacting individual education with local human capital. The results reported in table 3 indicate that human capital in the area raises the probability of training of workers with an upper secondary degree, while it does not affect those with tertiary education.

Thus, our findings not only indicate that local knowledge spillovers are mostly generated by concentration of upper secondary graduates, but also that they advantage especially workers with this level of education. On the contrary, the presence of tertiary graduates does not seem to play a relevant role. This result could be explained by the quite low percentage of tertiary degrees in the Italian LLMs (it varies from $1.87 \%$ to $13.05 \%$, with an average level of $7.98 \%$, see table 1). Indeed, in many endogenous growth models, human capital must be above a certain threshold level for any knowledge spillover effect to take place at all (Temple 2001). An alternative explanation for this result is that the prevailing technological and organisational profile of firms in Italy, characterised by traditional productions and a low degree of radical innovation, generates a knowledge which is complementary to more practical and tacit skills rather than to academic and highly formalised ones. This is also consistent with the fact that the percentage of local employment in $R \& D$ does not have a significant influence in our estimations. Similarly, Colombo and Stanca (2008) obtains that the impact of training on productivity is positive and large for blue collar, smaller for clerks and even negative for executives.

\section{Robustness checks}

In this section we test the robustness of our results. A potential problem with the estimation of equation [1] is the presence of unobservable heterogeneity and spatial sorting. More precisely, the positive correlation between local human capital and employer-provided training could be generated by selective migration of abler individuals across local labour markets. If people with higher ability tend to move to local areas characterized by higher average level of schooling, the correlation between training and local human capital may partially reflect unobserved ability rather than 
schooling externalities. In this case the coefficient of aggregated human capital should be upward biased.

To deal with this problem we included among the regressors some variables able to capture important components of individual ability (i.e. individual education, working experience, the size of the firm, the type of contract and a dummy for high schooling marks) and, secondly, we perform a Blundell and Smith test to verify whether local human capital, conditional on the control for unobserved heterogeneity, can be treated as weakly exogenous (the same strategy has been followed by Brunello and Gambarotto, 2006).

This test consists of two steps. In the first one local human capital is regressed on the set of exogenous variables as well as on an additional instrument. As an instrument we need a variable correlated with local human capital but not correlated with training. We use the LLM share of population aged between 0 and 7 in 1995. Indeed, because of compulsory schooling system, local demographic structure in 1995 is strongly related to local level of education in 2005 but, at the same time, it is unlikely to be correlated with local employer-provided training. Thus it can be expected that LLMs characterized by a larger share of 0-7 children in 1995 experienced in 2005 an increase in the percentage of residents who completed primary and lower secondary school (but not upper secondary school). That is, these LLMs should be characterised by a larger proportion of people who completed, at most, 8 years of schooling in 2005. Since average schooling in 2005 was above 8 years (table 1), a larger share of residents under the age of 7 in 1995 will tend to reduce the local human capital level in 2005. Results of the first regression indicate that the estimated coefficient of the share of population aged 0-7 in 1995 is significant (and negative). In this case the additional instrument is not weak (Angrist and Krueger 2001).

In the second step the residuals of the previous regression are included as an additional variable in equation [1]. Results given in table 4 show that the effect of the residuals from the first step regression are not significantly different from zero, which leads us to reject the hypothesis of no weak exogeneity of local human capital. This further confirms that the positive and significant effect of this variable on training is no spurious.

So far our key results have been proved stable even adopting alternative measures of local human capital. Now we check whether changes in sample selection affect estimations outcomes. Thus we replicate our estimations on males and females 
separately, on individuals aged 25 to 55 and, finally, on those employed in manufacturing industries.

Results are given in table 5 and show that the relationship between local human capital (in this case we consider the percentage of upper secondary graduates) and employer-provided training is robust to changes in the sample. In particular the share of population with an upper secondary degree in the LLM exerts a significantly positive influence on training as for male workers, those aged 25 to 55 and those employed in manufacturing industries. By contrast, this influence disappears when female workers are considered, even after controlling for additional individual characteristics such as marital status and having children, which are expected to influence strongly females behaviour in the labour market. Our analysis does not allow to explore further this asymmetry between males and females. Possible explanations can refer to a different composition of diplomas held by females and males ${ }^{4}$, to other not observed factors which tend to differentiate these two groups or, finally, to employers' discrimination.

\section{Concluding remarks}

According to results from recent research education gives rise to externalities increasing productivity and wages in the economy. As emphasised by these studies knowledge diffusion and learning are strengthened by proximity. This paper has tried to examine whether knowledge spillovers play some role in explaining training investments by firms. Unlike previous papers, our analysis has focused on area-specific measures of human capital, rather than on economic density, as a source of externalities increasing training incidence. We have analysed also the effects of other variables measuring distinctive features of local labour markets.

Our key-results are consistent with the prediction that training should be more frequent in areas where the aggregate educational level is higher. Interaction between local and individual human capital is positive and significant especially for those with an upper secondary educational attainment. Moreover, these results have proved to be robust since they were not altered when different definitions of local human capital are adopted or different sub-samples are considered (with the exception of female workers). We further proved their robustness by implementing a two-step strategy

\footnotetext{
${ }^{4}$ In our dataset males result to be concentrated on technical diplomas while females on teachers' training diplomas.
} 
based on instrumental variables in order to cope with the problem of omitted variables and spatial sorting stressed by the relevant literature as a possible cause of bias of econometric estimations.

As regards policy implications, our findings offer a rationale for public intervention. Indeed, positive externalities represent a symptom of market failure which could be addressed by proper policy measures. To this regard the impact of local knowledge spillovers on training suggests that the effectiveness of training policies could be improved if they would be considered as a part of integrated measures aiming at fostering the creation and diffusion of knowledge even by reinforcing interactions among agents in the economy.

Moreover, our results indicate that local externalities depend on the share of upper secondary graduates in the LLM and are mostly exploited by workers with an upper secondary degree. Thus, at the actual stage of Italian economic development, some priority should be given to the reduction of the number of early school leavers (young people aged 18-24 with at most lower secondary education level). Indeed, the percentage of early school leavers decreased in Italy from $31.7 \%$ in 1996 to $19,2 \%$ in 2007, but it remains higher than the EU27 average (15,2\%) according to Eurostat data.

Finally, we have found that more intense job turnover tends to lower private training investments possibly because of increased employment instability. Thus, policy intervention could be recommended when the local economy undergoes rapid structural changes which require larger workforce skills adaptation but depress firms incentives to training.

\section{References}

Acemoglu D., Pischke J. (1998), Why do firms train? Theory and evidence, Quarterly Journal of Economics, 113.

Acemoglu D., Pischke J. (1999), The structure of wages and investment in general training, Journal of Political Economy, 107.

Angrist J., Krueger A., (2001) Instrumental Variables and the Search for Identification: From Supply and Demand to Natural Experiments, Journal of Economic Perspectives, 15, pp.6985.

Arulampalam W., Booth A.L., Bryan M.L. (2003), Training in Europe, discussion paper N.933, IZA, Bonn.

Bassanini A., Booth A.L., Brunello G., De Paola M., Leuven E. (2007), Workplace training in Europe, in Brunello G., Garibaldi P., Wasmer E. (eds.), Education and training in Europe, Oxford University Press, Oxford.

Booth A.L., Zoega G. (2008), Worker heterogeneity, new monopsony, and training, Labour, 22. 
Brunello G., Medio A. (2001), An explanation of international differences in education and workplace training, European economic review, 45.

Brunello G., Gambarotto F. (2007), Do spatial agglomeration and local labor market competition affect employer-provided training? Evidence from the UK, Regional Science and Urban Economics, 37.

Brunello G., De Paola M. (2008), Training and economic density: some evidence from Italian provinces, Labour Economics, 15.

Ciccone A., Peri G. (2006), Identifying human-capital externalities: theory with applications, Review of economic studies, 73.

Colombo E., Stanca L. (2008), The impact of training on productivity: evidence from a large panel of firms, mimeo.

Conti G. (2005), Training, productivity and wages in Italy, Labour economics, 12.

Dalmazzo A., De Blasio G. (2007), Social returns to education in Italian local labor markets, Annals of regional sciences, 41 .

Di Addario S., Patacchini E. (2008), Wages and the city. Evidence from Italy, Labour Economics, 15.

Duranton G., Puga D. (2004), Microfoundations of urban agglomeration economies, in Henderson J.V., Thisse J.F. (eds.), Handbook of urban and regional economics, vol.4, Elsevier, North Holland.

Henderson J.V. (2007), Understanding knowledge spillovers, Regional Science and Urban Economics, 37.

Istat (2007), Rapporto annuale sulla situazione del Paese nel 2006, Rome.

Leuven E. (2005), The economics of private sector training, Journal of economic surveys, 19.

Moretti E. (2004), Estimating the social return to higher education: evidence from longitudinal and repeated cross-sectional data, Journal of econometrics, 121.

Muehlemann S. and Wolter S.C. (2006), Regional effects on employer provided training: evidence from apprenticeship training in Switzerland, CESifo working paper N. 1665.

Rauch J. (1993), Productivity gains from geographic concentration of human capital: evidence from the cities, Journal of urban economics, 34.

Rosenthal S.S., Strange W.C. (2004), Evidence on the nature and sources of agglomeration economies, in Henderson J.V., Thisse J.F. (eds.), Handbook of urban and regional economics, vol.4, Elsevier, North Holland.

Stevens M. (1996), Transferable training and poaching externality, in A.L. Booth and D.J. Snower (eds.), Acquiring skills. Market failures, their symptoms and policy responses, Cambridge University Press, Cambridge.

Temple J.R.W. (2001), Growth Effects of Education and Social Capital in the OECD Countries, CEPR Discussion Paper No. 2875 University of Bristol - Department of Economics; Centre for Economic Policy Research (CEPR), July.

Trigilia C., Ramella C. (2008) (eds.), Imprese e territori dell'alta tecnologia in Italia, Rapporti di Artimino sullo sviluppo locale.

Trivellato U., Paggiaro A., Leombruni R., Rosati S. (2005), La dinamica recente della mobilità dei lavoratori, 1998-2003, in B. Contini and U. Trivellato (a cura di), Eppur si muove. Dinamiche e persistenze nel mercato del lavoro italiano, il Mulino, Bologna. 


\section{Appendix A: Tables}

Table 1 - Descriptive statistics

\begin{tabular}{|c|c|c|c|c|c|}
\hline Variable description & Obs/freq & Mean & Std. Dev & Min & Max \\
\hline \multicolumn{6}{|l|}{ Dependent variables } \\
\hline Employer provided training & 1399 & 0.2004298 & 0.4003507 & 0 & 1 \\
\hline \multicolumn{6}{|l|}{ Individual characteristics } \\
\hline Females & 3522 & 0.5045845 & 0.5000148 & 0 & 1 \\
\hline Males & 3458 & 0.4954155 & 0.5000148 & 0 & 1 \\
\hline Married & 6980 & 0.5624642 & 0.4961184 & 0 & 1 \\
\hline Children & 6980 & 0.7882521 & 0.4085763 & 0 & 1 \\
\hline 20-29 years & 2478 & 0.3550143 & 0.4785519 & 0 & 1 \\
\hline 30-39 years & 1850 & 0.265043 & 0.4413877 & 0 & 1 \\
\hline $40-49$ years & 818 & 0.117192 & 0.3216719 & 0 & 1 \\
\hline $50-64$ years & 1834 & 0.2627507 & 0.4401597 & 0 & 1 \\
\hline Age & 6980 & 37.64971 & 11.47239 & 20 & 64 \\
\hline Max Elementary education & 270 & 0.0386819 & 0.1928496 & 0 & 1 \\
\hline Lower secondary education & 1611 & 0.2308023 & 0.4213764 & 0 & 1 \\
\hline Upper secondary education & 4152 & 0.5948424 & 0.4909577 & 0 & 1 \\
\hline Tertiary education & 947 & 0.1356734 & 0.3424659 & 0 & 1 \\
\hline Average years of schooling & 6980 & 12.21576 & 3.364239 & 0 & 20 \\
\hline High marks & 6980 & 0.4362464 & 0.4959544 & 0 & 1 \\
\hline Specific experience: more than 10 years & 6980 & 0.37851 & 0.4850504 & 0 & 1 \\
\hline Part-time & 1373 & 0.2057237 & 0.4042598 & 0 & 1 \\
\hline Permanent contract & 5848 & 0.8378223 & 0.3686401 & 0 & 1 \\
\hline \multicolumn{6}{|l|}{ Firm characteristics } \\
\hline Production of goods & 2583 & 0.3700573 & 0.4828543 & 0 & 1 \\
\hline Production services & 1109 & 0.160585 & 0.3671743 & 0 & 1 \\
\hline Distribution services & 1898 & 0.2748335 & 0.4464627 & 0 & 1 \\
\hline Personal services & 658 & 0.0952795 & 0.2936218 & 0 & 1 \\
\hline Social services & 658 & 0.0952795 & 0.2936218 & 0 & 1 \\
\hline Small firm (10-49 employees) & 4480 & 0.6418338 & 0.4794957 & 0 & 1 \\
\hline Medium firm (50-499 employees) & 1856 & 0.2659026 & 0.4418443 & 0 & 1 \\
\hline Large firm (500 or more employees) & 644 & 0.0922636 & 0.2894184 & 0 & 1 \\
\hline \multicolumn{6}{|l|}{ LLM's variables } \\
\hline \multicolumn{6}{|l|}{ Average Human capital per LLM } \\
\hline Average years of schooling per LLM & 6980 & 8.714633 & 0.6813844 & 5.85 & 10.019 \\
\hline$\%$ of tertiary degree per LLM & 6980 & 7.982072 & 2.500051 & 1.87 & 13.05 \\
\hline$\%$ of Upper secondary degrees per LLM & 6980 & 26.63542 & 3.14822 & 13.682 & 33.242 \\
\hline $\begin{array}{l}\text { \% of tertiary and upper secondary degree per } \\
\text { LLM }\end{array}$ & 6980 & 34.61737 & 5.309959 & 15.56 & 46.15 \\
\hline \multicolumn{6}{|l|}{ "Density" indicators per LLM } \\
\hline Population per LLM & 6980 & 714817.6 & 989746.6 & 5442 & 3374511 \\
\hline Employees per kmq per LLM & 6980 & 248.9661 & 303.2063 & 2.764 & 1143.031 \\
\hline \multicolumn{6}{|l|}{ "Productivity" indicators per LLM } \\
\hline Added Value per employee per LLM & 6980 & 50243.05 & 7265.363 & 20745.72 & 64379.23 \\
\hline \multicolumn{6}{|l|}{ Labour markets characteristics per LLM } \\
\hline R\&D \% of employees per LLM & 6980 & 24.23823 & 24.17779 & 0 & 170.773 \\
\hline $\begin{array}{l}\text { Sectorial changes in employment per LLM } \\
\text { (gross job turnover) }\end{array}$ & 6980 & 3.21219 & 1.904162 & .299 & 18.13 \\
\hline Average firms' size per LLM & 6980 & 8.408119 & 2.865969 & 1.471 & 21.073 \\
\hline Unemployment rate per LLM & 6980 & 4.726225 & 3.441326 & 0.92 & 15.95 \\
\hline Sector specialization per LLM & 6980 & 0.917765 & .0274742 & 0 & 1 \\
\hline \multicolumn{6}{|l|}{ Instrumental variable } \\
\hline $\begin{array}{l}\text { Share of population aged between } 0 \text { and } 7 \\
\text { years in } 1995\end{array}$ & 6980 & 7.105878 & 1.484562 & 3.98 & 12.34 \\
\hline \multicolumn{6}{|l|}{ Macroarea } \\
\hline North West & 1979 & .2835244 & .4507409 & 0 & 1 \\
\hline North East & 1699 & .2434097 & .4291711 & 0 & 1 \\
\hline Centre & 1400 & .2005731 & .4004578 & 0 & 1 \\
\hline South & 1359 & .1946991 & .3959973 & 0 & 1 \\
\hline Islands & 543 & .0777937 & .2678659 & 0 & 1 \\
\hline
\end{tabular}


Table 2 - Probit estimates of the probability of employer-provided training: individual, firmspecific and local effects

\begin{tabular}{|c|c|c|c|c|c|c|c|c|}
\hline \multirow[t]{2}{*}{ Varaibles } & \multicolumn{2}{|c|}{ (1) } & \multicolumn{2}{|c|}{ (2) } & \multicolumn{2}{|c|}{ (3) } & \multicolumn{2}{|c|}{ (4) } \\
\hline & Coeff. & $\mathrm{Z}$ & Coeff. & $\mathrm{z}$ & Coeff. & $\mathrm{z}$ & Coeff. & $\mathrm{z}$ \\
\hline Female & $-0.29883^{* *}$ & -6.93 & $-0.30184 * *$ & -6.97 & $-0.3021 * *$ & -6.97 & $-0.30266^{* *}$ & -6.99 \\
\hline 30-39 years & $0.146003^{* *}$ & 2.76 & $0.139618^{* *}$ & 2.62 & $0.138124 * *$ & 2.6 & $0.137573^{* *}$ & 2.58 \\
\hline $50-64$ years & 0.064571 & 1.03 & 0.054461 & 0.86 & 0.053239 & 0.84 & 0.051696 & 0.82 \\
\hline Lower sec. education & $0.353946^{*}$ & 2.23 & $0.335309 *$ & 2.13 & $0.335407 *$ & 2.13 & $0.33513 *$ & 2.13 \\
\hline Upper sec. education & $0.894969 * *$ & 5.8 & $0.867386 * *$ & 5.66 & $0.867762 * *$ & 5.66 & $0.867657 * *$ & 5.66 \\
\hline Tertiary education & $1.087921 * *$ & 6.7 & $1.048936^{* *}$ & 6.48 & $1.049094 * *$ & 6.49 & $1.048897 * *$ & 6.48 \\
\hline High marks & $0.158136^{* * *}$ & 4.01 & $0.158065^{* *}$ & 4.00 & $0.15759 * *$ & 3.99 & $0.15673 * *$ & 3.96 \\
\hline $\begin{array}{l}\text { Specific experience: more } \\
\text { than } 10 \text { years }\end{array}$ & $0.266428 * *$ & 5.48 & $0.270438 * *$ & 5.54 & $0.270813 * *$ & 5.55 & $0.271454 * *$ & 5.56 \\
\hline Part time & $-0.34003^{* *}$ & -6.12 & $-0.34723^{* *}$ & -6.23 & $-0.34655^{* *}$ & -6.22 & $-0.34609 * *$ & -6.21 \\
\hline Permanent contract & $0.192372 * *$ & 2.88 & $0.196276^{* *}$ & 2.93 & $0.196348 * *$ & 2.93 & $0.195534 * *$ & 2.92 \\
\hline Medium firm (50-499) & $0.208654 * *$ & 4.91 & $0.206692 * *$ & 4.86 & $0.207137 * *$ & 4.87 & $0.206541 * *$ & 4.85 \\
\hline Large firm (500 or more) & $0.373645 * *$ & 6.2 & $0.369447 * *$ & 6.07 & $0.3694 * *$ & 6.07 & $0.369644 * *$ & 6.07 \\
\hline $\begin{array}{l}\% \text { of Upper Secondary } \\
\text { graduates }\end{array}$ & & & $0.019863^{*}$ & 2.23 & - & - & 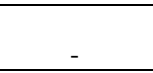 & - \\
\hline $\begin{array}{l}\% \text { of Upper Secondary } \\
\text { and Tertiary graduates }\end{array}$ & & & & & $0.013163 *$ & 2.07 & - & - \\
\hline $\begin{array}{l}\text { Average years of } \\
\text { schooling }\end{array}$ & & & & & & & $0.123737 *$ & 2.08 \\
\hline Log Employment density & & & -0.01267 & -0.33 & -0.0131 & -0.34 & -0.01854 & -0.48 \\
\hline$\%$ of employees in R\&D & & & -0.00014 & -0.13 & -0.00047 & -0.4 & -0.00061 & -0.51 \\
\hline $\begin{array}{l}\text { Log Added Value per } \\
\text { employee }\end{array}$ & & & -0.03257 & -0.15 & -0.0292 & -0.13 & -0.04797 & -0.21 \\
\hline Sector specialization & & & 0.032482 & 0.37 & 0.033467 & 0.38 & 0.01723 & 0.2 \\
\hline Unemployment rate & & & 0.009672 & 0.66 & 0.012479 & 0.82 & 0.012678 & 0.84 \\
\hline Average firm size & & & -0.00123 & -0.13 & 0.000393 & 0.04 & 0.001285 & 0.14 \\
\hline Log population & & & -0.00537 & -0.15 & -0.01237 & -0.33 & -0.01299 & -0.34 \\
\hline Job turnover & & & $-0.0282 *$ & -2.37 & $-0.02632 *$ & -2.22 & $-0.02595^{*}$ & -2.18 \\
\hline Constant & $-2.08335^{* *}$ & -12.32 & -2.0458 & -0.91 & -1.93619 & -0.85 & -2.32696 & -1.04 \\
\hline Industrial dummies & \multicolumn{2}{|c|}{ Yes } & \multicolumn{2}{|c|}{ Yes } & \multicolumn{2}{|c|}{ Yes } & \multicolumn{2}{|c|}{ Yes } \\
\hline Territorial dummies & \multicolumn{2}{|c|}{ Yes } & \multicolumn{2}{|c|}{ Yes } & \multicolumn{2}{|c|}{ Yes } & \multicolumn{2}{|c|}{ Yes } \\
\hline
\end{tabular}

$* * 1 \%$ significance level; * 5\% significance level 
Table 3 - Probit estimates of the probability of employer-provided training: local effects and cross dummies between individual and local

\begin{tabular}{|c|c|c|c|c|c|c|c|c|c|c|c|c|}
\hline \multicolumn{13}{|c|}{ human capital } \\
\hline \multirow[b]{2}{*}{ Variables } & \multicolumn{2}{|l|}{ (1) } & \multicolumn{2}{|c|}{ (2) } & \multicolumn{2}{|l|}{ (3) } & \multicolumn{2}{|l|}{ (4) } & \multicolumn{2}{|l|}{ (5) } & \multicolumn{2}{|c|}{ (6) } \\
\hline & Coef. & $\mathrm{z}$ & Coef. & $\mathrm{z}$ & Coef. & $\mathrm{Z}$ & Coef. & $\mathrm{z}$ & Coef. & $\mathrm{z}$ & Coef. & $\mathrm{z}$ \\
\hline Female & $-0.30119 * *$ & -6.95 & $-0.30166^{* * *}$ & -6.96 & $-0.30172 * *$ & -6.96 & $-0.3019 * *$ & -6.97 & $-0.3032 * *$ & -6.99 & $-0.30278^{* * *}$ & -6.99 \\
\hline $30-39$ years & $0.136926 * *$ & 2.57 & $0.138962 * *$ & 2.61 & $0.136741^{* *}$ & 2.57 & $0.137836^{*}$ & 2.59 & $0.136062 *$ & 2.56 & $0.136857 * *$ & 2.57 \\
\hline $40-49$ years & 0.11253 & 1.59 & \begin{tabular}{|l|}
0.112522 \\
\end{tabular} & 1.59 & 0.111996 & 1.59 & 0.111205 & 1.57 & 0.110866 & 1.57 & \begin{tabular}{|l|}
0.110137 \\
\end{tabular} & 1.56 \\
\hline $50-64$ years & 0.056008 & 0.89 & 0.053979 & 0.85 & 0.054954 & 0.87 & 0.052953 & 0.84 & 0.052509 & 0.83 & 0.051138 & 0.81 \\
\hline Lower secondary education & $0.353937^{*}$ & 2.23 & $0.334283^{*}$ & 2.12 & $0.355211^{*}$ & 2.24 & $0.33412^{*}$ & 2.12 & $0.357613^{*}$ & 2.26 & $0.332928^{*}$ & 2.11 \\
\hline Upper secondary education & -0.05266 & -0.14 & $0.865817 * *$ & 5.65 & 0.200663 & 0.68 & $0.865939 * *$ & 5.65 & -0.45886 & -0.87 & $0.864931 * *$ & 5.64 \\
\hline Tertiary education & $1.093805^{* * *}$ & 6.69 & $1.248165^{* * *}$ & 2.58 & $1.099664 * *$ & 6.71 & $1.219983^{* * *}$ & 3.13 & $1.099509^{* *}$ & 6.71 & $1.557185^{*}$ & 2.21 \\
\hline High marks & \begin{tabular}{|l|l|l}
$0.15688^{* * *}$ \\
\end{tabular} & 3.96 & $0.158336^{* * *}$ & 4 & $0.156866^{* * *}$ & 3.97 & $0.157891^{* *}$ & 3.99 & $0.156379^{* *}$ & 3.95 & $0.157146^{* * *}$ & 3.97 \\
\hline Specific experience: more than 10 years & $0.270178 * *$ & 5.54 & $0.270685^{* * *}$ & 5.55 & $0.269915 * *$ & 5.53 & $0.270942 * *$ & 5.55 & $0.271045^{* * *}$ & 5.55 & $0.271688 * *$ & 5.57 \\
\hline Part time & $-0.34611 * *$ & -6.21 & $-0.34718 * *$ & -6.23 & $-0.34606 * *$ & -6.21 & $-0.34633^{* *}$ & -6.22 & $-0.34527 * *$ & -6.2 & $-0.34549 * *$ & -6.2 \\
\hline Permanent contract & $0.197713^{* * *}$ & 2.95 & $0.195856^{* * *}$ & 2.92 & $0.197443^{* *}$ & 2.95 & $0.195687^{* * *}$ & 2.92 & $0.197339^{* * *}$ & 2.95 & $0.194715^{* * *}$ & 2.9 \\
\hline Medium firm (50-499) & $0.208074 * *$ & 4.89 & $0.206824 * *$ & 4.86 & $0.207997 * *$ & 4.89 & $0.207383^{* *}$ & 4.87 & $0.207514 * *$ & 4.87 & $0.206965^{* *}$ & 4.86 \\
\hline Large firm (500 or more) & $0.372398^{* * *}$ & 6.11 & 0.370121 & 6.08 & $0.372306^{* *}$ & 6.11 & $0.370304 * *$ & 6.08 & $0.372529 * *$ & 6.11 & $0.371108 * *$ & 6.09 \\
\hline$\%$ of upper secondary graduates & -0.00307 & -0.25 & $0.020935^{*}$ & 2.26 & & & & & & & & \\
\hline Individual upper secondary $* \%$ of upper secondary & $0.035494 * *$ & 2.77 & & & & & & & & & & \\
\hline Individual tertiary $* \%$ of upper secondary & & & -0.00736 & -0.44 & & & & & & & & \\
\hline$\%$ of upper secondary and tertiary degrees & & & & & $6.96 \mathrm{E}-05$ & 0.01 & $0.013825^{*}$ & 2.12 & & & & \\
\hline Individual upper secondary $* \%$ of upper secondary and tertiary & & & & & $0.020082 * *$ & 2.65 & & & & & & \\
\hline Individual tertiary $* \%$ of upper secondary and tertiary & & & & & & & -0.0048 & -0.48 & & & & \\
\hline Average years of schooling & & & & & & & & & 0.021092 & 0.3 & $0.131345^{*}$ & 2.17 \\
\hline Individual upper secondary * average years of schooling & & & & & & & & & $0.155343 * *$ & 2.61 & & \\
\hline Individual tertiary * average years of schooling & & & & & & & & & & & -0.05745 & -0.74 \\
\hline Log Employment density & -0.01353 & -0.35 & -0.01321 & -0.34 & -0.01386 & -0.36 & -0.01357 & -0.35 & -0.01921 & -0.5 & -0.01902 & -0.5 \\
\hline \% of employees in R\&D & $-9.9 \mathrm{E}-05$ & -0.09 & -0.00012 & -0.11 & -0.00043 & -0.37 & -0.00044 & -0.37 & -0.00055 & -0.46 & -0.00055 & -0.46 \\
\hline Log Added Value per employee & -0.03191 & -0.14 & -0.03289 & -0.15 & -0.02754 & -0.12 & -0.02862 & -0.13 & -0.03768 & -0.16 & -0.04694 & -0.2 \\
\hline Sector specialization & 0.033241 & 0.38 & 0.032583 & 0.37 & 0.035474 & 0.41 & 0.033832 & 0.39 & 0.021577 & 0.25 & 0.018426 & 0.21 \\
\hline Unemployment rate & 0.008827 & 0.6 & 0.00932 & 0.63 & 0.012081 & 0.8 & 0.012165 & 0.8 & 0.012055 & 0.8 & 0.012165 & 0.8 \\
\hline Average firm size & -0.00076 & -0.08 & -0.00138 & -0.15 & 0.00087 & 0.09 & 0.000264 & 0.03 & 0.001679 & 0.18 & 0.001104 & 0.12 \\
\hline Log population & -0.00584 & -0.16 & -0.005 & -0.14 & -0.01335 & -0.35 & -0.01211 & -0.32 & -0.01443 & -0.38 & -0.01276 & -0.34 \\
\hline Job turnover & $-0.02869^{*}$ & -2.41 & $-0.02796 *$ & -2.35 & $-0.0265^{*}$ & -2.23 & $-0.02605^{*}$ & -2.19 & $-0.02592 *$ & -2.18 & $-0.02555^{*}$ & -2.15 \\
\hline Constant & -1.46147 & -0.65 & -2.0691 & -0.92 & -1.52013 & -0.67 & -1.96317 & -0.86 & -1.56044 & -0.7 & -2.40109 & -1.08 \\
\hline Industrial dummies & \multicolumn{2}{|l|}{ Yes } & \multicolumn{2}{|l|}{ Yes } & \multicolumn{2}{|l|}{ Yes } & \multicolumn{2}{|l|}{ Yes } & \multicolumn{2}{|l|}{ Yes } & \multicolumn{2}{|c|}{ Yes } \\
\hline Territorial dummies & \multirow{2}{*}{\multicolumn{2}{|c|}{ Yes }} & \multirow{2}{*}{\multicolumn{2}{|c|}{$\begin{array}{c}\text { Yes } \\
6612\end{array}$}} & \multirow{2}{*}{\multicolumn{2}{|c|}{$\begin{array}{c}\text { Yes } \\
6612\end{array}$}} & \multicolumn{2}{|l|}{$\begin{array}{c}\text { Yes } \\
6612\end{array}$} & \multirow{2}{*}{\multicolumn{2}{|c|}{$\begin{array}{c}\text { Yes } \\
6612\end{array}$}} & $\mathrm{Y}$ & \\
\hline Number of observations & & & & & & & 6612 & & & & \multicolumn{2}{|c|}{6612} \\
\hline Pseudo R2 & \multicolumn{2}{|c|}{$\begin{array}{c}0012 \\
0.1136\end{array}$} & \multicolumn{2}{|c|}{0.1125} & \multicolumn{2}{|c|}{0.1134} & \multicolumn{2}{|c|}{0.1124} & 0.1134 & & 0.1 & \\
\hline
\end{tabular}

** $1 \%$ significance level; * $5 \%$ significance level 
Table 4 - Probit estimates of the probability of employer-provided training, augmented with the residuals from the first step regression of the percentage of individuals with an upper secondary degree on the instrument (share of population aged between 0 and 7 years in 1995) - Blundell and Smith test

\begin{tabular}{|c|c|c|c|c|}
\hline Variables & Coef. & Std. Err. & $\mathbf{z}$ & $\mathbf{P}>|\mathbf{z}|$ \\
\hline Female & -0.29 & 0.043624 & -6.65 & 0 \\
\hline 30-39 years & 0.102376 & 0.055109 & 1.86 & 0.063 \\
\hline 40-49 years & 0.11676 & 0.070737 & 1.65 & 0.099 \\
\hline 50-64 years & 0.005541 & 0.066456 & 0.08 & 0.934 \\
\hline Lower secondary education & 0.303691 & 0.159643 & 1.9 & 0.057 \\
\hline Upper secondary education & -0.18837 & 0.370844 & -0.51 & 0.611 \\
\hline Tertiary education & 0.909336 & 0.179846 & 5.06 & 0 \\
\hline High marks & 0.162227 & 0.039653 & 4.09 & 0 \\
\hline Specific experience: more than 10 years & 0.275864 & 0.048898 & 5.64 & 0 \\
\hline Part time & -0.38728 & 0.058283 & -6.64 & 0 \\
\hline Permanent contract & 0.200361 & 0.067103 & 2.99 & 0.003 \\
\hline Medium firm (50-499) & 0.187181 & 0.043444 & 4.31 & 0 \\
\hline Large firm (500 or more) & 0.296986 & 0.06831 & 4.35 & 0 \\
\hline$\%$ of Upper Secondary graduates & 0.126963 & 0.054625 & 2.32 & 0.02 \\
\hline Individual upper secondary $* \%$ of upper secondary & 0.036222 & 0.012869 & 2.81 & 0.005 \\
\hline Log Employment density & 0.010109 & 0.039663 & 0.25 & 0.799 \\
\hline$\%$ of employees in R\&D & -0.00088 & 0.001171 & -0.75 & 0.452 \\
\hline Log Added Value per employee & 0.032395 & 0.22589 & 0.14 & 0.886 \\
\hline Sector specialization & 0.013852 & 0.087717 & 0.16 & 0.875 \\
\hline Unemployment rate & 0.02716 & 0.016477 & 1.65 & 0.099 \\
\hline Average firm size & 0.000993 & 0.009241 & 0.11 & 0.914 \\
\hline Log population & -0.01532 & 0.037186 & -0.41 & 0.68 \\
\hline Job turnover & -0.02238 & 0.012136 & -1.84 & 0.065 \\
\hline Residuals from first stage & -0.0118 & 0.075931 & -0.16 & 0.877 \\
\hline Constant & -5.55076 & 2.809837 & -1.98 & 0.048 \\
\hline Industrial dummies & \multicolumn{4}{|c|}{ Yes } \\
\hline Territorial dummies & \multicolumn{4}{|c|}{ Yes } \\
\hline Number of observations & \multicolumn{4}{|c|}{6612} \\
\hline Pseudo R2 & \multicolumn{4}{|c|}{0.1145} \\
\hline
\end{tabular}


Table 5 - Probit estimates of the probability of employer-provided training (males, females, aged 25-55, employed in manufacturing sector)

\begin{tabular}{|c|c|c|c|c|c|c|c|c|}
\hline \multirow[t]{2}{*}{ Variables } & \multicolumn{2}{|c|}{$\begin{array}{c}(1) \\
\text { Males }\end{array}$} & \multicolumn{2}{|c|}{$\begin{array}{c}(2) \\
\text { Females }\end{array}$} & \multicolumn{2}{|c|}{$\begin{array}{c}(3) \\
\text { Aged 25-55 }\end{array}$} & \multicolumn{2}{|c|}{$\begin{array}{c}\text { (4) } \\
\begin{array}{c}\text { Manufacturing } \\
\text { industries }\end{array} \\
\end{array}$} \\
\hline & Coef. & $\mathrm{Z}$ & Coef. & $\mathrm{Z}$ & Coef. & $\mathrm{z}$ & Coef. & $\mathrm{z}$ \\
\hline Female & & & & & $-0.32456^{* *}$ & -6.86 & $-0.52936^{* *}$ & -6.44 \\
\hline 30-39 years & 0.017328 & 0.21 & $\begin{array}{c}0.166508 * \\
*\end{array}$ & 1.97 & 0.083101 & 1.42 & 0.163534 & 1.65 \\
\hline $40-49$ years & 0.082037 & 0.87 & 0.094545 & 0.83 & 0.081369 & 1.1 & 0.207271 & 1.77 \\
\hline 50-64 years (a) & -0.07065 & -0.79 & 0.043048 & 0.38 & 0.020804 & 0.29 & -0.01186 & -0.11 \\
\hline $\begin{array}{l}\text { Lower secondary } \\
\text { education }\end{array}$ & $0.440785^{*}$ & 2.1 & 0.169356 & 0.66 & 0.251613 & 1.38 & 0.313873 & 1.38 \\
\hline Upper sec. education & -0.22701 & -0.47 & -0.0521 & -0.09 & -0.21922 & -0.54 & -0.64414 & -1.04 \\
\hline Tertiary education & $\begin{array}{c}1.093181 * \\
* \\
\end{array}$ & 4.78 & $\begin{array}{c}0.818251 * \\
* \\
\end{array}$ & 2.74 & $\begin{array}{c}0.917271^{*} \\
* \\
\end{array}$ & 4.5 & $\begin{array}{c}1.022004^{*} \\
*\end{array}$ & 3.4 \\
\hline High marks & $\begin{array}{c}0.180747 * \\
*\end{array}$ & 3.36 & $0.129468 *$ & 2.16 & $\begin{array}{c}0.159236^{*} \\
*\end{array}$ & 3.67 & $0.27271 * *$ & 3.96 \\
\hline $\begin{array}{l}\text { Specific experience: } \\
\text { more than } 10 \text { years }\end{array}$ & $0.30463 * *$ & 4.34 & $\begin{array}{c}0.290071 * \\
*\end{array}$ & 4.06 & $\begin{array}{c}0.262164 * \\
*\end{array}$ & 5.16 & $0.180437 *$ & 2.17 \\
\hline Married & & & -0.00022 & 0 & & & & \\
\hline Children & & & 0.096677 & 1.24 & & & & \\
\hline Part time & $-0.60118 * *$ & -3.96 & $-0.35303 * *$ & -5.11 & $-0.33133 * *$ & -5.38 & -0.18059 & -1.34 \\
\hline Permanent contract & $\begin{array}{c}0.324081 * \\
*\end{array}$ & 3.19 & 0.129055 & 1.38 & $\begin{array}{c}0.283224 * \\
*\end{array}$ & 3.46 & $\begin{array}{c}0.391531 * \\
* \\
\end{array}$ & 2.98 \\
\hline Medium firm (50-499) & $\begin{array}{c}0.168005^{*} \\
*\end{array}$ & 2.92 & $\begin{array}{c}0.246315^{*} \\
*\end{array}$ & 3.63 & $\begin{array}{c}0.195911^{*} \\
*\end{array}$ & 4.15 & $\begin{array}{c}0.304442 * \\
*\end{array}$ & 4.19 \\
\hline Large firm (500 or more) & $\begin{array}{l}0.305294^{*} \\
*\end{array}$ & 3.46 & $0.276685^{*}$ & 2.42 & $\begin{array}{c}0.355224^{*} \\
*\end{array}$ & 4.8 & $\begin{array}{c}0.452393 * \\
*\end{array}$ & 4.6 \\
\hline $\begin{array}{l}\% \text { of upper secondary } \\
\text { degrees }\end{array}$ & $\begin{array}{c}0.184378^{*} \\
*\end{array}$ & 2.61 & 0.039831 & 0.45 & $0.124614 *$ & 2.1 & $\begin{array}{c}0.127013 * \\
* \\
\end{array}$ & 2.48 \\
\hline $\begin{array}{l}\text { Individual upper } \\
\text { secondary } * \% \text { of upper } \\
\text { secondary }\end{array}$ & $\begin{array}{c}0.043359 * \\
*\end{array}$ & 2.57 & 0.026875 & 1.32 & $\begin{array}{c}0.036837 * \\
*\end{array}$ & 2.64 & $0.053617 *$ & 2.42 \\
\hline Log Employment density & 0.008944 & 0.17 & 0.011488 & 0.19 & 0.028771 & 0.66 & 0.028264 & 0.42 \\
\hline$\%$ of employees in R\&D & -0.00299 & -1.78 & 0.001379 & 0.82 & -0.00061 & -0.48 & $-0.00443^{*}$ & -2.01 \\
\hline $\begin{array}{l}\text { Log Added Value per } \\
\text { employee }\end{array}$ & 0.040677 & 0.14 & 0.033127 & 0.09 & 0.168178 & 0.68 & -0.1336 & -0.35 \\
\hline Sector specialization & -0.01416 & -0.13 & 0.039296 & 0.27 & -0.0237 & -0.25 & -0.04594 & -0.3 \\
\hline Unemployment rate & 0.036252 & 1.71 & 0.015711 & 0.58 & 0.022589 & 1.25 & 0.0207 & 0.75 \\
\hline Average firm size & 0.000675 & 0.06 & -0.00152 & -0.1 & 0.001977 & 0.2 & -0.00933 & -0.62 \\
\hline Log population & -0.0086 & -0.17 & -0.00818 & -0.14 & -0.0318 & -0.78 & 0.021727 & 0.34 \\
\hline Job turnover & $-0.0354^{*}$ & -2.19 & -0.00535 & -0.28 & -0.02325 & -1.76 & -0.02294 & -1.13 \\
\hline Residuals from first stage & -0.09818 & -0.97 & -0.05298 & -0.06 & -0.09851 & -1.65 & -0.11841 & -1.52 \\
\hline Constant & $-7.31812 *$ & -2.02 & -3.77114 & -0.81 & -5.87158 & -1.89 & -3.90797 & -0.87 \\
\hline Sector of econ. activity & \multicolumn{2}{|c|}{ Yes } & \multicolumn{2}{|c|}{ Yes } & \multicolumn{2}{|c|}{ Yes } & \multicolumn{2}{|c|}{ No } \\
\hline Territorial dummies & \multicolumn{2}{|c|}{ Yes } & \multicolumn{2}{|c|}{ Yes } & \multicolumn{2}{|c|}{ Yes } & \multicolumn{2}{|c|}{ Yes } \\
\hline Number of observ. & \multicolumn{2}{|c|}{3295} & \multicolumn{2}{|c|}{3317} & \multicolumn{2}{|c|}{5474} & \multicolumn{2}{|c|}{2518} \\
\hline Pseudo R2 & \multicolumn{2}{|c|}{0.1331} & \multicolumn{2}{|c|}{0.1095} & \multicolumn{2}{|c|}{0.1149} & \multicolumn{2}{|c|}{0.1265} \\
\hline
\end{tabular}

** $1 \%$ significance level; * 5\% significance level

(a) 50-55 for estimations reported in column (3). 